\title{
Look right: The conservative elites opposing Thailand's protesters
}

Edition 4, 2020

Emeritus Professor Kevin Hewison

DOI: 10.37839/MAR2652-550X4.10

Thailand's military-backed government has declared a state of emergency as it experiences unprecedented challenges to its monarchy, which is protected by state repression backed by several draconian laws. On October 14, in the centre of Bangkok, a royal motorcade was enveloped by protesters who hurled insults at its passengers-a situation never seen before. In an earlier rally, on September 20, thousands of protesters marched on the offices of the Privy Council to present a list of ten reforms demanded of the monarchy.

Confronting the monarchy in this manner is a brave. Between 2006 and 2017, dozens were charged, arrested, and jailed for lèse-majesté (to insult or defame the monarch), and since then many more have been charged with sedition, computer crimes and related charges for actions deemed offensive to the monarch. Challenging the monarchy also brings activists into conflict with right-wing royalists and a bureaucratic and ideological system that has for decades lauded the monarchy and rejected criticism as "un-Thai."

Much recent attention has been given to the student-led movement. But understanding the forces of reaction is clearly important in understanding Thailand's current political conflict, particularly the interconnected loyalists that push back against calls for more democracy and all "transgressions" against the monarchy. 


\section{Monarchy and Military}

The recent student-led demonstrations and demands for political and monarchy reform place Thailand at a critical juncture, with the alliance of monarchy and military challenged for the first time. That alliance has been at the heart of the country's political status quo for several decades.

By taking on the King, the activists have a most powerful opponent. Vajiralongkorn has immense economic and political power. His personal wealth in 2019 was estimated at about US\$70 billion, controlling vast expanses of land in Bangkok and two of the country's largest corporations. Even with such massive wealth, the royal family receives enormous taxpayer funding - set at more than US\$1 billion for the fiscal year 2021. One of the criticisms of the monarchy has focused attention on the huge amount spent on "protecting" and "revering" the King and his family. Taxpayer funding keeps the royal family living in luxury and also maintains an extensive ideological apparatus that projects the King as the "father of the nation," responding to emergencies, sponsoring good deeds, and caring for his people. Such promotion has been more difficult to sustain when the King spends much of his time-and most of 2020-living in Germany. Even so, his "presence" in Thailand must still be managed and "protected" by the regime with vast resources spent, including the time of hundreds of ministers and senior bureaucrats who must repeatedly demonstrate loyalty. The monarchy's ideological position is maintained by every state agency, through all media, and through all educational institutions. In Vajiralongkorn's short time on the throne, particular energy has been expended in removing memorials to the end of the absolute monarchy in 1932. Such memorials conflicted with Vajiralongkorn's developing neo-traditionalism and apparent preference for royal absolutism. Considerable effort has also gone to the development of quasi-military Royal Thai Volunteers, composed mostly of soldiers, bureaucrats and others who uphold the monarchy, who work to make the absent King "present" and "connected" to his country. 
On becoming King, Vajiralongkorn inherited some of the political influence that his father had aggregated, but he has also amassed considerable political clout through revisions to the 2017 constitution and the transfer of palace administration and thousands of police and military to his personal control, further blurring the lines between palace and military. Maintaining the monarchy's prestige relies on the government and military, working together to stamp out anti-monarchism. The current government and its military predecessor have conceptualised the monarchy as a keystone of the conservative ruling elite. In responding to rising criticism of the monarchy, the regime has charged and jailed hundreds. Some believe that the regime is also responsible for the enforced disappearance and murder of several anti-monarchy activists living in exile.

The King's view of the protests is not publicly known, but as a military man who demands obedience and who is prone to erratic and furious behaviour, it is likely that he views the protesters as, at best, an irritant and most probably as a threat to the throne. While he ordered that lèse-majesté no longer be used, presumably because it was causing considerable international criticism, is Vajiralongkorn orders a crackdown on his critics, the regime's track record is of giving him what he wants.

Loyalty to the monarchy motivates the military leadership. Unlike previous generations of the military's top brass, the current leadership made their careers through service to the throne rather than through combat. With more than 360,000 active and 200,000 reserve personnel and a 2019 budget of more than $\$ 7.5$ billion, the military has been a powerful defender of the political status quo. Its history of domestic political repression, serial coup making, and a penchant for opening fire on demonstrators makes it a dangerous opponent. Some observers emphasise schisms within the military and between its leadership and the government of Thailand's Prime Minister, General Prayuth Chan-ocha. Yet the military-monarchy alliance trumps such factionalism, and this alliance has controlled and shaped Thailand's politics for long periods since the late 1950s. Today, the military's leadership is trenchantly royalist and backs Prayuth's government in opposing students and others it identifies as anti-monarchists. 
The military has spent considerable effort propagating Vajiralongkorn's military credentials, emphasizing his military training and his brief active service in the army's anti-communist counterinsurgency in the 1970s. It has developed an ideology that positions Thailand as a "democratic country with the King as the head of state" and titular head of the armed forces. This "Thai-style democracy" is a particular construct that downplays electoral democracy and promotes royalism. Those who promote electoral politics are therefore regarded as opponents of monarchy and military. The King has cemented his control over the military and has filled his palace with former officers. For example, only three of the Crown Property Bureau's 11-member board do not have military rank.

In recent years, the regime has allocated significant effort and large budgets to internal psychological warfare aimed at expunging anti-monarchism. A critical agency in the military and regime effort to defeat political opponents is the Internal Security Operations Command (ISOC), which is credited with defanging the red shirts after 2010. Charged with defending the nation, religion, and monarchy, ISOC links the military and civilian administration making it, as scholar Puangthong Pawakapan explains, "a potent tool with which conservative elites can undermine and control electoral democracy and through which the military can maintain its power." Its well-funded operations run in parallel with civilian agencies and most notably with the powerful Ministry of Interior, with a network of agents and officials throughout the country. The primacy of its work is enacted in legislation and orders that mean that all state agencies must abide by ISOC's plans and with ISOC supervision. Its activities include surveillance that extends to the community level and online, developing, funding and mobilising right-wing groups, the harassment and detention of political opponents and the disruption of their activities. In recent years, as Puangthong argues, ISOC has been a counter-democracy agency, making it a powerful and dangerous opponent of pro-democracy students. 


\section{Judiciary}

Since the 2006 military coup, the judiciary has also been fashioned as an ally of monarchy and military in the struggle for "Thai-style democracy." It had been accused of politicisation before 2006, when then Prime Minister Thaksin Shinawatra tried to influence the Constitutional Court, but it was Vajiralongkorn's father, King Bhumibol's exhortation to the judiciary to sort out a political "mess" that saw judges drawn openly into the political fray. Since then, the judiciary, and the Constitutional Court in particular, has consistently acted to support the conservative elite against elected governments and political parties considered oppositional. The judiciary has become a reliable ally of the conservative and royalist political elite, banning politicians, dissolving political parties, and protecting military-backed regimes. Most recently, in an act that ignited the student movement, the Constitutional Court dissolved the avantgarde Future Forward Party.

The Constitutional Court and the independent agencies created by the 1997 constitution and maintained by the more recent post-coup constitutions of 2007 and 2017, have worked against elected governments and political oppositions to preserve the interests and power of the royalist elite. The Criminal Court and military courts have reinforced this movement by assiduously patrolling the boundaries of politics and commentary and have been especially active in suppressing criticism of the monarchy. From 2006 to 2017, the principal means for this has been the use of the draconian Article 112 of the Criminal Code (the lèse-majesté law) and the equally fierce Computer Crimes Act. Since 2017, the opposition has also been targeted with charges of sedition, treason, and computer crimes.

\section{Rightists and Royalists}

The state's actions against political oppositions garner the support of a range of conservatives. The royalists mobilised on October 14 included scores of police officers and soldiers, dressed in yellow shirts, and trucked in to support the groups 
already organised by a coterie of royalist groups and their leaders.

This century, the first major royalist movement was the People's Alliance for Democracy (PAD). It was organised in 2005, seeking to bring down the Thaksin government. PAD used the monarchy in a symbolic manner to undermine Thaksin, whom it accused of anti-monarchism. The movement became known as yellow shirts because, in a display of loyalty, its followers wore shirts in the colour associated with Bhumibol's day of birth. Like the military leadership, yellow shirts considered the monarchy essential to "Thai-ness," viewing anti-monarchism as treasonous and a threat to national security. PAD's actions led to the 2006 coup against Thaksin and the judicial removal of a pro-Thaksin government in 2008 .

Since PAD, other right-wing groups have emerged regularly, claiming to be protecting the monarchy while attacking those it considers anti-monarchy or trespassing on the monarchy's expanding political turf. In various periods of political conflict, groups espousing rightist royalism have been brought together to uphold conservative values and politics. Not all have attracted the mass support that PAD enjoyed, but their role has been to demonstrate civilian support for military-backed politics. Probably reflecting the work of ISOC, some of these groups appear to have been testing the political waters and developing a monarchist panic that have sometimes resulted in larger mobilisations. These groups included the Thai Patriot Network (2008), Multi Colours (2010), Siam Samakkhi (2011), Pitak Siam (2012), Rubbish Collection Organisation (2014-20), and the People's Democratic Reform Committee or PDRC (2013). Some, like Pitak Siam, have been led by retired military officers and adopt what one commentator called a "neo-fascist ultra-right" position. Pitak Siam prepared the political ground for the PDRC that eventually became the street movement demanding that Yingluck Shinawatra's elected government be ousted. When the coup came in May 2014, the PDRC cheered and several of its leaders are now in powerful positions, including current cabinet ministers like Minister of Digital Economy and Society Buddhipongse Punnakanta.

In a manner eerily reminiscent of the emergence of rightist groups in earlier periods 
of political struggle, a "new" yellow shirt band has been initiated to oppose students. Thai Pakdee (Loyal Thais) is an ultra-royalist group that mixes the symbolism of earlier yellow shirts and the PDRC. Its chief motivator is long-time yellow shirt Warong Dechgitvigrom, who was previously associated with the royalist Democrat Party and the PDRC. Thai Pakdee demands protection of the monarchy, rejects constitutional change, and wants the regime "enforce the law" by charging those it considers anti-monarchy. Warong rejects electoral democracy as divisive, blaming the country's ills on "politicians," and believes it is former Future Forward Party politicians who are the puppet masters of the current pro-democracy movement.

Like other rightists, Thai Pakdee deals in conspiracy theory in painting the studentled movement as dangerously "un-Thai." The creation of "plots" has often preceded bouts of extremism and political violence. It was anti-monarchist "communists" who were massacred at Thammasat University in 1976. Thaksin was falsely accused of concocting a plot in Finland in 2006 that would bring down the monarchy. This time, Thailand's royalists have adopted views and rhetoric close to the US Alt-Right, rejecting democracy and liberalism. The current movement is (falsely) claimed to be a Central Intelligence Agency-mounted "Colour Revolution", funded by foreign capitalists and the US government. One result was Thai Pakdee and other rightists demonstrating at the US Embassy in Bangkok, demanding that it stop backing the students. Former PAD leader Sondhi Limthongkul has re-emerged to support such conspiracy claims.

When yellow-clad royalists assembled to oppose protesters on October 14, they included Thai Pakdee and the Rubbish Collection Organisation, with the PDRC's Suthep Thaugsuban also calling out his supporters. As already mentioned, this familiar cast of royalists were buttressed by disguised police and troops. These events emphasised that where the student-led protesters are an organic movement, the rightists rely heavily on the state. 


\section{Democracy vs monarchy}

Calls for a more democratic Thailand are not new. Where the student-led demonstrators break new ground is in demanding that an over-reaching King be brought under legal control. But trailblazing demands inevitably generate opposition, and in Thailand it has been rightists and royalists who have held sway for decades. Convincing them of the need for change is no easy task when they feel that the monarchy is the social, political, and ideological glue that holds Thailand together. With the state arresting many of the leaders of the movement, avoiding conflict becomes even more challenging.

Main image: Protests in Bangkok, 2008. Credit: Craig Martell - originally posted to Flickr as Bangkok Protests on 26 August 2008. 